\title{
PPIUCD versus interval IUCD (380a) insertion: a comparative study in a referral hospital of Karnataka, India
}

\author{
Hema Mohan, Rekha Ramappa*, Sandesh M., Akash B. K.
}

Department of Obstetrics \& Gynaecology, Shimoga Institute of Medical Sciences, Shimoga, Karnataka, India

Received: 07 October 2015

Revised: 15 October 2015

Accepted: 30 October 2015

\section{*Correspondence: \\ Rekha Ramappa, \\ E-mail: rekhsr@yahoo.com}

Copyright: (c) the author(s), publisher and licensee Medip Academy. This is an open-access article distributed under the terms of the Creative Commons Attribution Non-Commercial License, which permits unrestricted non-commercial use, distribution, and reproduction in any medium, provided the original work is properly cited.

\section{ABSTRACT}

Background: Comparative evaluation of PPIUCD and interval IUCD in terms of incidence of failure, expulsions, bleeding $\mathrm{p} / \mathrm{v}$ and other complications.

Methods: Total 200 willing women after counseling in antenatal, early labour or post natal were inserted PPIUCD after excluding chorioamnionitis, PROM $>18 \mathrm{hrs}$, unresolved PPH, puerperal sepsis. Another 100 willing women were inserted interval IUCD after excluding contraindications. All were followed up to 6 months.

Results: Expulsions rate was significantly higher in PPIUCD as compared to interval insertions (5.5\% v/s 5\%). Number of removal of IUCD was almost similar in both the groups $(6.5 \% \mathrm{~V} / \mathrm{S} 7 \%)$. Common causes of PPIUCD removal were social.

Conclusions: Postpartum inserting of IUCD is safe effective, feasible and reversible method of contraception.

Keywords: PPIUCD, Interval IUCD, Acceptance, Safety

\section{INTRODUCTION}

As per 2011 census, the population of India is 1.21 billion; postpartum family planning services are an ideal platform to reposition family planning. The vast majority of men want avoid unexpected pregnancy for at least 2 yrs after delivery. Increase in institutional deliveries across the country has created excellent opportunity to provide quality postpartum family planning services. Inserting $\mathrm{Cu}-\mathrm{T} 380 \mathrm{~A}$ at $10 \mathrm{~min}$ after placental delivery using Kelly's forceps is leading to safe expanding of usage of IUCD in majority unmet needs. This study is hence done to evaluate PPIUCD.

The objective of the study was to evaluate PPIUCD in comparison to interval IUCD interms of incidence of failure, expulsion, bleeding PV, pain abdomen and other complications.

\section{METHODS}

The present study was a prospective observational study conducted in 300 women in Shimoga Institute of Medical Sciences, Shimoga, during the period of March 2015 to September 2015. 100 in immediate postpartum IUCD group (100 in normal vaginal delivery group and caeserian section group.100 in interval IUCD group. Inclusion criteria were, all patients coming to labour room in early labour who gave consent for PPIUCD insertions were included and all patients who came for interval IUCD were included. Exclusion criteria included chorioamnionitis, puerperal sepsis, PROM >18hrs, potentially infected dhai handling cases, uncontrolled PPH. All patients who accepted this method,Cu-T380A was placed fundally by using Kelly's forceps after placental delivery in vaginal delivery and sponge holding forceps before closure of uterine incision in caesarian.

Follow up was done at $15^{\text {th }}$ day, $6^{\text {th }}$ week and $6^{\text {th }}$ month; results were compared with interval IUCD. 


\section{RESULTS}

Women in the age group 20-25 were more willing; eventually they were councilled during a period.

Expulsion occurred in 11cases after immediate PPIUCD, 8 of which in vaginal delivery group. 3expulsion happened interval IUCD group (Table 2).

IUCD were removed in 13 subjects, 8 of which were in vaginal delivery group, 11 subjects had their CU-T380A removed in interval group.
Table 1: Total acceptance rate of PPIUCD.

\begin{tabular}{|llll|}
\hline $\begin{array}{l}\text { Age } \\
\text { group } \\
\text { (Yrs) }\end{array}$ & $\begin{array}{l}\text { Total no } \\
\text { of } \\
\text { deliveries }\end{array}$ & $\begin{array}{l}\text { Number of cases } \\
\text { who accepted } \\
\text { PPIUCD }\end{array}$ & $\%$ \\
\hline$<20$ & 50 & 5 & $10 \%$ \\
\hline $20-25$ & 1002 & 119 & $11.8 \%$ \\
\hline $26-30$ & 984 & 67 & $6.8 \%$ \\
\hline $30-35$ & 78 & 7 & $8.9 \%$ \\
\hline$>35$ & 50 & 2 & $4 \%$ \\
\hline Total & 2164 & 200 & 41.5 \\
\hline
\end{tabular}

Table 2: Expulsion rate in IUCD.

\begin{tabular}{|llllll|}
\hline Type of insertion & Primi-para $(\mathrm{n}=4 \mathbf{4})$ & Multi-para $(\mathrm{n}=\mathbf{1 5 6})$ & Total expulsions & $\%$ & P value \\
\hline Vaginal delivery $(\mathrm{n}=100)$ & $2(4.5 \%)$ & $6(3.8 \%)$ & 8 & $8 \%$ & 0.04 \\
\hline T.C $(\mathrm{n}=100)$ & 0 & $3(1.9 \%)$ & 3 & $3 \%$ & 0.04 \\
\hline Interval group $(\mathrm{n}=100)$ & $1(0.67 \%)$ & $3(3 \%)$ & 5 & $5 \%$ & \\
\hline
\end{tabular}

Complication occurred in 48 cases of PPIUCD, and 31 cases of interval group. Most common complication in PPIUCD-Vaginal delivery group was expulsion, while in transcaesarean group was bleeding. Most common complication in interval group was pain abdomen.

\section{DISCUSSION}

The PPIUCD is a highly effective, long acting, reversible, cost effective and easily accessible family planning method that is safe for used by most postpartum women including those who are breast feeding.
Table 3: Continuation rate.

\begin{tabular}{|lrcc|}
\hline PPIUCD & $\begin{array}{l}\text { Number } \\
\text { of cases }\end{array}$ & $\begin{array}{l}\text { Continuation } \\
\text { over } 6 \text { months }\end{array}$ & $\%$ \\
\hline $\begin{array}{l}\text { Vaginal } \\
\text { delivery }\end{array}$ & 100 & 84 & $84 \%$ \\
\hline T.C & 100 & 92 & $92 \%$ \\
\hline $\begin{array}{l}\text { Interval } \\
\text { group }\end{array}$ & 100 & 84 & $84 \%$ \\
\hline
\end{tabular}

Table 4: Complication after IUCD insertion.

\begin{tabular}{|llllllll|}
\hline Clinical presentation at follow-up & V.D & $\%$ & T.C & $\%$ & Interval & $\%$ & P value \\
\hline Bleeding & 3 & $3 \%$ & 10 & $10 \%$ & 10 & $10 \%$ & 0.283 \\
\hline W.D p/v & 4 & $4 \%$ & 5 & $5 \%$ & 3 & $3 \%$ & 0.532 \\
\hline Pain abdomen & 4 & $4 \%$ & 8 & $8 \%$ & 12 & $12 \%$ & 0.071 \\
\hline PID & 0 & $0 \%$ & 0 & $0 \%$ & 0 & $0 \%$ & 0 \\
\hline Missing threads & 1 & $1 \%$ & 2 & $2 \%$ & 1 & $1 \%$ & 0.722 \\
\hline Expulsions & 8 & $8 \%$ & 3 & $3 \%$ & 5 & $5 \%$ & 0.856 \\
\hline Total & 20 & $20 \%$ & 28 & $28 \%$ & 31 & $31 \%$ & \\
\hline
\end{tabular}

The total acceptance rate of PPIUCD in our study was 41.5\%.Majority of the cases who accepted PPIUCD, belonged to the age group 20-25 yrs. This was probably because most of the patients who came to hospital for delivery also belonged to the age group 20-25 yrs.
The result in our study showed that expulsion rate following vaginal PPIUCD in present study were 5.5\%, the expulsion after trans caesarean insertion occurred in $5 \%$ cases, which is comparable with the results of study of Muller ALL et al. ${ }^{1}$ In our study rate of expulsion PPIUCD was significantly higher in the normal vaginal delivery group than in trans caesarean group. 
This lower expulsion rate in transcaeserean insertion as compared to vaginal insertion may be due to direct placement of IUCD at the fundus during caeserian section.

The rate of expulsion in interval IUCD group in our study was $5 \%$ which was same as in PPIUCD group 5.5\%. The expulsion rate was significantly higher in vaginal delivery group that is $8 \%$.

The cumulative rate of removal over 6months follow up after PPIUCD insertion was $6.5 \%$.The rate removal interval insertion group in our study was $7 \%$, which is similar to PPIUCD group.

Table 5: Causes of removal of IUCD over a period of 6 months.

\begin{tabular}{|lcccccc|}
$\begin{array}{l}\text { Causes of } \\
\text { removal }\end{array}$ & V.D & $\%$ & T.C & $\%$ & Interval & $\%$ \\
\hline $\begin{array}{l}\text { Social } \\
\text { causes }\end{array}$ & 5 & $5 \%$ & 1 & $1 \%$ & 0 & $0 \%$ \\
\hline Bleeding & 1 & $1 \%$ & 2 & $2 \%$ & 5 & $5 \%$ \\
\hline $\begin{array}{l}\text { Discharge } \\
\text { p/v }\end{array}$ & 0 & $0 \%$ & 0 & $0 \%$ & 0 & $0 \%$ \\
\hline $\begin{array}{l}\text { Pain } \\
\text { abdomen }\end{array}$ & 0 & $0 \%$ & 2 & $2 \%$ & 5 & $5 \%$ \\
\hline PID & 0 & $0 \%$ & 0 & $0 \%$ & 0 & $0 \%$ \\
\hline $\begin{array}{l}\text { For } \\
\text { conception }\end{array}$ & 2 & $2 \%$ & 0 & $0 \%$ & 1 & $1 \%$ \\
\hline $\begin{array}{l}\text { Other } \\
\text { methods }\end{array}$ & 0 & $0 \%$ & 0 & $0 \%$ & 0 & $0 \%$ \\
\hline Total & 8 & $8 \%$ & 5 & $5 \%$ & 11 & $11 \%$ \\
\hline
\end{tabular}

In our study the complications were seen in $24 \%$ cases who had immediate PPIUCD insertion .Expulsion was the most common complication in the vaginal group (8 $\%$, while in transcaserean group bleeding $\mathrm{p} / \mathrm{v} 10 \%$ was the most common complication. No case of PID/Endometritis reported in our study. EL Beltagy et al also reported no increase in the incidence PID after immediate postpartum IUCD insertion. ${ }^{2}$ No case of perforation were reported from both the groups. This decrease risk of uterine perforation may be because of thick wall of the uterus.

The cumulative rate of complication in our study was $24 \%$ in PPIUCD group and $31 \%$ interval IUCD group ( $24 \%$ and $31 \%$ ) respectively. Comparison ( $p$ value) with respect to each complication shows that difference is not significant. This was in accordance with the study Eroglu et al and Ricalde et al where the rates of complication did not differ significantly between the two groups. 3,4
The most common reason for PPIUCD removal in our study were bleeding and pain which account for removal in 25 cases $(12.5 \%)$. The continuation rate in our study was about $88 \%$ for PPIUCD over a study period of 6 months. On comparing the interval IUCD with PPIUCD slightly higher continuation rate were obtained in PPIUCD group than interval group (84\%).

\section{CONCLUSIONS}

From the above study we came to the conclusion that postpartum insertion of PPIUCD is safe effective, feasible and reversible method of contraception.

Compared with the interval insertions, postpartum insertions do not increase the risk of infections or endometrits, bleeding, perforation. Nor do they affect the return of uterus to normal size .Particularly noteworthy is very low rates of perforation in the postpartum period because of the thickened uterine walls.

IUCDs if safely inserted in immediate postpartum period and included as a part of obstetrical management of the patient.

\section{Funding: No funding sources \\ Conflict of interest: None declared \\ Ethical approval: The study was approved by the Institutional Ethics Committee}

\section{REFERENCES}

1. Bonilla Rosales F, Aguilar Zamudio Me, Cazares Montero ML, Hernaderz Ortiz ME, Luna Ruiz MA. Factors for expulsion of intrauterine device 380A applied immediately postpartum and after delayed period. Rev Med Inst Mex Seguro Soc. 2005;43(1):5-10.

2. EL Beltagy NS, Darwish EA, Kasem MS, Hefila NM. Comparison between Cupper T380 IUD and Multiload 375 IUD in early post-partum insertion. East fertility Society J. 2010;16:143-8.

3. Eroglu K, Akkuzu G, Vural G, Dilbaz B, Akin A, Taskin L, et al. Comparison of efficacy and complication of IUD insertion in immediate. Postplacental/early postpartum period with interval period: 1 year follow-up. Contraception. 2006;74:376-81.

4. Ricalde Roger Lara. Gerardo Menocal Tobias. Carlos Ramos Perez. Norma Velazquez Ramirez. Estudiocomparativo al azar Cu375 y Tcu 380A colocados durante el postparto. Ginecol Obstet Mex. 2006;74:306-11.

Cite this article as: Mohan H, Ramappa R, Sandesh M, Akash BK. PPIUCD versus interval IUCD (380a) insertion: a comparative study in a referral hospital of Karnataka, India. Int J Reprod Contracept Obstet Gynecol 2015;4:1730-2. 